\title{
IN THE SHADOWS OF INTERPRETATION: MANIPULATIVE NATURE OF TRANSLATION IN COLLIDING OF SACRAL AND MARGINAL
}

\author{
LIUDMYLA GARNYK \\ Department of International Relations, Kharkiv Petro Vasylenko National \\ Technical University of Agriculture \\ Alchevskih 44, 61002 Kharkiv, Ukraine \\ E-mail address: milla.garnyk@gmail.com \\ ORCID: https://orcid.org/0000-0003-0983-9323
}

\section{YURII VITKOVSKYI}

Marketing \& Economics Department, Kharkiv Petro Vasylenko National Technical University of Agriculture

Alchevskih 44, 61002 Kharkiv, Ukraine

E-mail address: vice-rector@khntusg.info

ORCID: https://orcid.org/0000-0001-5806-8671

KHUSAMEDDIN AL-KHALAVANI

NGO Center of international relations "Peace and Security"

Office 13, Lipkovskogo 14/18, 03035 Kyiv, Ukraine

E-mail address: husamhalawani@yahoo.com

ORCID: https://orcid.org/0000-0002-2921-3013

\begin{abstract}
Aim. Aim of the article is to provide critical examination of manipulation process as multidimensional phenomenon related to imagination, representation, translation and interpreting of original texts in light of assurance of informational safety that is our research object. Our research corresponds to theory and practice of translation, psychology, comparative religious studies, international relations, public diplomacy and national security.

Methods. Research methodology is based on critical analysis of manipulations with texts; the methods have been borrowed from works of Gilbert Durand (1999), Michel Maffesoli (1996) and James Frazer (2012) on social anthropology.

Results. Practical value of obtained results consists in proposed algorithm for critical analysis of translated or interpreted texts that allows to evaluate their quality according to context, meaning and semiotics of the source texts. The notion of empire as an archetype that was implemented into contemporary international relations is also revised
\end{abstract}

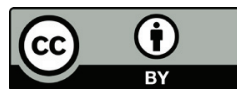


and extended. That can help in analysis and prevention of different forms and means of outside and inside tactics of deviant influence on societies and to illuminate threats for cultural identity and spiritual diversity of the global community.

Conclusions. Phenomenon of marginalisation of cultural and spiritual identity (sacral sphere) under the influence of globalisation by the means of soft power pressure can be evaluated today as the unspoken impact of influence agents implemented into new societal institutes in the form of alien cultural imperatives that are enforced to different communities as common for all agendas in the frameworks of postmodern stream.

Key words: translation, interpretation, international relations and diplomacy, informational security, manipulations, cross-cultural communication, management, marginal and sacral, archetype theory

\section{INTRODUCTION}

$\mathrm{D}$ igital era started in the $21^{\text {st }}$ century has one initial difference related to the dominance of digital technologies and promotion of mass-consumption as the key matrix of economic behaviour; altogether, these become main features of postmodern Leviathan that rules over contemporary societal domain. According to Koert van Bekkum et al. (2017), Leviathan is a symbolic emanation of idolatrous, demonic, utterly negative and mentally deviated eternal element of a human being. Moreover, Leviathan is traditionally mentioned as demythologising symbol of evil spiritual reality coherent to Thomas Hobbes' interpretation of powerful state that controls all spheres of social and private life. That is why anybody who is able to control information channels and operates with information technologies can create, collate, manage and manipulate store or share information beyond the frameworks of time and space. Other significant features of this era are the role of information as a unique societal and economic resource; it is also the key factor in modern production and consumption. Information is also considered as a tool for obtaining competitive advantages at political, managerial, organisational and global levels. However, information can very often be isolated from its original context, deviated, translated, changed, rethought, reshaped and reinterpreted in different ways for political, economical, administrative or any other purposes by the means of manipulative techniques, especially in the postmodern age.

According to the suggestion of Michel Maffesoli (1996), postmodernity, much alike to contemporary community modus, is characterised by such features as individualism, instrumental reasons, omnipotence of technique and economy-centered attitudes and assumptions, also changing the role of founding myths and marginalised (or simplified to populism) values implemented into communitarian ideal or into archetypes as much more mature elements of the unconscious that are coherent with sacral sphere. The situation described here can be observed in the case of the democratic ideal that was saturated and replaced by its communitarian counterparts. This usually is represented as return of images, symbolisms (i.e. affirmations of religious identification, ethnic effervescence, search for "territory" etc.) and other elements of the matrix for a budding 
sociality or things that constitute the cultural stew of which the headlines represent to us constellations of patterns that defined more or less explosive nature of human being. This is evident for the former eastern empires and is consistent with numerous movements that affect different countries of the so-called "third world." But contemporary western countries - those of the first world, a product of modernity - are nowadays themselves in the state of profound crisis. Archetype of "the second world" empire represented by American societal model that aspires to obtain global leadership by promotion of a new world order has illusive nature like colossus with feat of clay. It was clearly illustrated by Gambatista Vico's "ricorci" concept - if in brief - imaginal ideas and common myths, serving "collective genius" (anomic today and canonic tomorrow maxima) - conditions and regulators of possibility for any kind of social life. This notion is synonymic to Wilfred Pareto's "residues" and Patrick Tacussel's "social attraction" with regards to their meaning of a "collective ego" implemented in the nation-state and the archetypal nature of power and dominance.

Following the notion that postmodernism is an elusive concept colliding domains of different fields of science (Laugharne \& Laugharne, 2002), despite of clear pattern of postmodern thought reflecting reactions and rejections of some philosophical truths and objectivity and other elements underlying modernism, we can agree that postmodern (or post-conventional) scientific discourse aspires to expand its frameworks by incorporating different types and kinds of verification into the processes of generating new knowledge that is needed in cases when its expertise should be mediated by the means of gaining the public consensus.

Anyhow, today we have faced with transformation of essentional principles into main goals, when quality has been replaced by truth. That is the reason why scientific research activity now is the key element of the process and viewpoints of scholars are open to challenges. The aspects mentioned above became triggers stimulating interpretations, manipulations and illusive assumptions as products of marginalisation processes inside and beyond sacral sphere, defined by Carl Gustav Jung as a basic element of collective unconscious based on marginal perception of sacral symbols (McLeod, 2018).

That is why the purpose of research lies in critical examination of manipulation as multidimensional phenomenon related to translation, interpreting and sharing information within the society to generate influence (or control) on its political, economic, cultural and social development. For example, phenomena of soft power, hybrid and consciental wars as well as building of radical sectarian or terroristic networks and their ideologies around the globe are based on manipulation aimed at achieving absolute control on people by cardinally reshaping their mental, cultural, historical and spiritual self-identity.

Usually, agents of influence (politicians, sectarian leaders or radical extremists) use different manipulative techniques for crowd management to create needed public opinion or attract new followers. But the most popular of them is gambling with meanings of sacral texts by interpreting them or their translated parts as citations without any regard to consisted in their original versions 
semantic or semiotic constructs, contexts or idioms. Thus, critical and comparative analysis as elements of research methodology allow for systemising different kinds of manipulations related to translated and/or interpreted texts with proficiency requirements for translators of texts belonging to different genres. For verification of our research hypothesis we have also applied social anthropology and approaches borrowed from scientific heritage of James Frazer (2012) and Gilbert Durand (1999).

Our working hypothesis is as follows: if information can be considered power existing in the form of data, then it is valuable in evaluation of any object or societal phenomenon. We take arguments to validate this hypothesis from theory and practice of translation, philosophic anthropology, political science, psychology, public administration, comparative religious studies and national security issues.

\section{TRANSLATION OR INTERPRETATION: ASPECTS OF THEORY AND PRACTICE}

Discussing translation as a phenomenon, as well as its impact on everyday life, Eugene Nida has stated that: "interlingual translations are based on two factors: semantic similarities between languages due no doubt in large measure to the common core of human experience and fundamental similarities into syntactic structures of languages especially at the so-called kernel or core level" (Nida, 1969, pp. 483-485). Usually the term "translation" is used in practice in different meanings as: general subject field, result of intellectual activity or act of translator's activity. At the same time, the process of interlingual translation is related to translator's activity whose aim is to change the original text produced in one verbal language into a written text in other ones (Jakobson, 1959). Interlingual translation, according to Nicola Dusi and Roman Jakobson, " can be divided into categories: proper translation or interpretation of verbal signs by means of some other language; and intersemiotic translation or transmutation - interpretation of verbal signs by the means of signs of non-verbal sign systems"' (Jakobson, 1959, p. 233; Dusi, 2015).

The term "manipulation," in light of journalist's or translator's activity, inspires wide polemics between scholars, who have recognised it as "the most controversial aspect of national security management" (Kuey, 2020, pp. 154157), and others, who consider that "manipulation defines a proficiency level of translator or journalist" (Dukate, 2009, pp. 43-44). Manipulations can also be sorted by frequency of their occurrence in texts or around them. According to research of Aiga Dukate, each kind of described below manipulations also can have different forms as like as: overt and covert, avoidable and unavoidable, mandatory and optional ones. For example, according to her notion, if overt manipulation is "kind of manipulation that is announced for instance in preface or in text itself indicating its parts that have been manipulated," then covert is "not announced manipulation." 
Usually avoidable manipulation occurs if translator or text handler has enriched the text by new element, but this change can be avoided to transfer meaning in the most close to original text manner. In the case with unavoidable manipulation, "translator (or text handler) has had any choose then opts for the solution chosen usually due to linguistic peculiarities of the target language." Anyhow conscious manipulation has avoidable (or partly-avoidable) character whereas conscious has not, since translator is not aware of it.

Another kind of manipulations, known as obligatory or mandatory ones, usually are "caused by linguistic differences and optional manipulation overlaps with conscious and unconscious manipulations, but here are also certain tracing differences. Mandatory manipulations or obligatory shifts can be perceived as legitimate translation strategies, as we have discussed earlier and optional manipulations or optional shifts as manipulation in conventional sense of the word, or handling and devious change, respectively" (Dukate, 2007, pp. 105-106).

Also Dukate has underlined that "manipulation as kind of translational and interpretational strategy which in turn is manifested as a shift in the translator's or interpreter's output in comparison with original text" (Dukate, 2009, p. 76). That is why main features of translator's activity models should be analysed (see Table 1).

Table 1

Models of translator's activity

Model of translation
process

1 Situational model Basis of language units for translated and original texts is their correlation with elements and phenomena of objective reality (denotes, referents).

2 Semantic model Translation is reduced to component analysis of translated text units and meaning synthesis in relevant units of target language. Level of semantic resemblance between original and translated text defines measure of its adequacy and quality.

3 Transformational Translation is based on operations on transforming of nuclear syntactic structures that are equivalent in different languages.

4 Communicative Translation is defined as act of bilingual communication, when language is kind of code reflecting relationship between: signs, symbol and denotation, signs and communicators.

5 Informative Translation is based on the idea that any text is source of various information - semantic, stylistic, functional, situational, aesthetic, and so on; the translation is based on available information equivalents in language.

6 Language Main task of translation is to establish logical correspondences differences model between elements of original and translated text (equivalence, contextual differences etc.), also with forms and diapasons of its primary meaning interpretations. This model is logically related with theoretical and practical aspects of translator's work on poetry texts. 


\begin{tabular}{|c|c|c|}
\hline$\#$ & $\begin{array}{c}\text { Model of translation } \\
\text { process }\end{array}$ & Main characteristics and features \\
\hline 7 & $\begin{array}{l}\text { Transfer of sacred } \\
\text { and religious texts } \\
\text { meanings model }\end{array}$ & $\begin{array}{l}\text { Translation of spiritual and sacred texts meanings must } \\
\text { take into consideration their thematic orientation, genre } \\
\text { affiliation, civilisational, cultural aspects and historical } \\
\text { context as like as its interpretations, lexical and grammatical } \\
\text { equivalents, communicative aims of translator and cultural } \\
\text { axiology of language-recipient. Here translation as process is } \\
\text { coherent with interpretation and transformation as essential } \\
\text { elements of translator's activity that requires availability } \\
\text { of special education, professionalism in this field and high } \\
\text { spiritual level of person in general. Persons without required } \\
\text { proficiency level on this field are often faced with risks to } \\
\text { create objects for manipulation (i.e. "translated» texts) or } \\
\text { became subjects of manipulations. This usually occurs when } \\
\text { dilettante-translator is motivated by agents of influence (for } \\
\text { example political group or radical sect) to transform original } \\
\text { meanings of religious texts for purposes of spreading } \\
\text { conflicts and contradictions among people or communities. } \\
\text { Such activity is key element of modern consciental } \\
\text { (hybrid) wars, where information is the main weapon } \\
\text { (Duskers, 2020). }\end{array}$ \\
\hline
\end{tabular}

Source: completed by authors.

Finally we can totally agree with Dukate's notion that "above-made distinction between manipulation as handling, manipulation as improvement and manipulation as distortion, it can be said that manipulation in these two senses has optional character. But in the same time, it one considers the external pressures exerted on text handler, these types of manipulation can also be seen as mandatory ones. Manipulation as handling can be so far optional as text handler can decide not to handle some particular text at all" (Dukate, 2009, pp. 110-112). Regarding mandatory and optional kinds of manipulation, here purpose of translation should also be considered.

\section{BETWEEN DIVINE AND MARGINAL: POSTMODERN OR ETERNAL}

Postmodernity deviates or even eliminates the role of many classical scientific methods and instruments of disciplines in the humanities by their marginalisation in the period of 20th early 21st centuries, demarking inevitable (in the nearest future) societal crisis and as its result: change of world order. Works of Paul-Michel Foucault, Jacques Derrida and Gilles Deleuze, much alike those of the medieval Sufi mystics, clerics-philosophers and their civic colleagues were focused on demarking symbolic borders of human being by means of logics, defining the nature of human being implemented in archetypes, symbols, myths, sacral and imaginary worlds, elements of faith and ima- 
gination, issues relevant to serenity of mind and mental illness, searching sense and senseless in the nature of things.

Balancing between sacral and marginal, logics and imagination, members of intellectual community "Eranos School" (Hakl, 2014) have developed a unique method named "Eranos tagungen" that helped to observe and describe different elements of a human being concerning its nature as multidimensional coordinate system, aspiration to eternal return and mediation between sacral and marginal domains. Among members of "Eranos School" we can underline such names as Carl Jung, Rudolf Otto, Mircea Eliade, Karl Kerenyi, Erich Neumann, Adolf Portmann, Gilbert Durand and Anri Corben, who have played a key role in facilitating exchange of knowledge between eastern and western intellectuals. Followers of Jungian ideas of collective ignorance, whose research area was focused on studying of symbols, archetypes, myths, classical theology, post-modern philosophy, nature and social studies, linguistics and theosophy joined the "Eranos" gatherings as permanent members. The variety of observed research objects were implemented into set original approaches and instruments for analysis of human's nature concerning the positions of its flexibility in time and space. Thus, each person exists on a crossroad which centralises different dimensions of human being and triggers of influence are collided and reinterpreted.

Here we can debate whether an intellectual's historical role and his/her impact on the development of societal domain if he or she can be: manipulators or manipulated figures, agents of influence or silent victims of outside influence, blind religious fanatics or scholars who develop knowledge by operating by new technologies. There is no any clear answer according to nature of postmodern reality and to illustrate this we can discuss works of leading scholars related with "Eranos Shool."

Spiritual realm of self also known as "imaginal" or imaginary space was interpreted in equivalent philosophic terms and represented to western community by Mircea Eliade (2005), Anri Corbin (1983) and Rudolf Otto (1958); there, angels and numinous beings exist, and religious philosophy and exploration of visionary faith created essential elements of transcendental meditation in tradition of Persian-Islamic mysticism. Their works reflect elements of Sufi theory of knowledge, divinity and journey within the soul also known as "le rituel de la coupe," bright insight as a reaction on dipping into philosophic multiversum of Persian mysticism's heritage represented by works of Sohravardi, Ibn Arabi and Shirazi, trigged by borrowed constructs from writings of Ismaili Gnostics like medieval philosopher Nasr-i Khusraw, who was converted into ismailism during their journey to Egypt (Corbin, 1983).

Corbin implemented reinterpreted Ismaili ideas into his works, including the aspiration to purify religious imagination from elements of fundamentalism. That was his great contribution into studying the role and place of imagination in human (marginal) life, ethical norms and divine-spiritual human values (Corbin, 1983). His colleague Eliade proposed the theory of "eternal return" as an extension of Rene Genon's ideas about sacral and marginal inter- 
pretation close to Ismaili's classical doctrine. He introduced a theory based on the concept of "cyclic time" that explains the origins of customs, taboo, social institutes, traditions and their everyday practices. He was also the first theorist of societal topos that was demarked as eternal space where "logos" and "mythos" domains coexist and collide. Domain of "mythos" is traditionally represented as a myth about "eternal return" where "logos" can be recognised as a milestone, background or turning point of linear temporality also known as "social time" (Eliade, 2005).

However, our interest was attracted by wide polemics around heritage of Silvestre de Sacy on comparative linguistics, Orientalism and interlingual translation (de Sacy, 1842). His works provide an original theory on etymology of the words "assassin" (murder, killer, terrorist, spy), "assassinate," "assassination" that appeared in many European languages since in medieval Crusades. According to de Sacy, these words are close related to the name of influential radical sectarian movement called "assassins" (spies and killers) in Europe or "hashihins" (people who use "hashish" or herbal drug) in the Arab lands. Alternative reading is provided by Sergey Plekhanov (2008, pp. 6-7), grounding his opinion on contemporary Ismaili's open resources, that the word "assassin" takes its origin from Arabic words "asas" ("background") and "al-ass" ("those who have got divine right to interpret and represent to community teaching of prophet"). According to Ismailit's version, Ali Abu Thalib was "al-ass of Prophet Muhammad in whom god has implemented divine part of his sacral nature" (Plekhanov, 2008, pp. 6-7); after Ali there were myriad of his successors by consanguinity till present days. Despite this, in the world historical heritage we can find many of different controversial facts relevant to "assassins." Today members of this group are also known as religious community, who accepts Karim Aga Khan IV as their Prince and current Ismaili Imam. This prince-imam lives in Europe but has near 15 millions of followers in more than 25 countries of the world. The nature of his authority within and beyond Ismaili community can be observed even in light of postmodernity as phenomena of leadership and sacralisation of mythos about "eternal" and religion-based empire (Poor, 2014).

Here we should make digression to clarify a point about postmodern connotation of empire as an instrument and institute of contemporary space (or multiversum) of international relations and cultural diplomacy. In the frameworks of these multiversum non-state actors, business diplomats, their international networks, including different NGOs and their alliances, usually play the roles of so-called "supra-territorial" component that undermines sovereignty of nation-state by limiting its performance as key actor of international economic relations. That is why nowadays, for many nation-states influenced by globalisation and competition for foreign direct investment, a partnership is desirable with non-state actors, who specialise in economic and commercial diplomacy, to improve the effectiveness of serving their interests in socio-economic and business spheres.

Nowadays, many state actors, especially ministries of foreign affairs, aim to extend their institutional capabilities to deal with non-state actors. Unfortuna- 
tely they often demonstrate negligence to the effective management dilemma that originated from the controversial nature of contemporary societal-economic reality. In contrast, Western soft power strategies (traditions) reinterpreted through the Islamic viewpoint (innovations) and practically implemented by new key players (Muslim communities) around the world. The instruments and strategies described here are mostly applicable if state has semi-authoritarian or misbalanced political system (Garnyk et al., 2020). The fact that soft power strategies are not the only postmodern instrument that facilitates international actors to set up total control on state and its politics by soft and silent penetration through its national public and economic spheres may sound like an unusual idea to some. Thus, despite wide polemics on the issue, interpretation, as method of manipulation, and activity of translators, as agents of influence (soft power), on our opinion, are originated from historical moment of foundation of the first empire.

In terms of Durand's "Imaginer" (Durand, 1999), each religious community is close to the metaphorical "house of friends" ("nocturnal regime") rather than to the myth about eternal empire where political and spiritual leadership is concentrated in the hands of one despot: a king and the successors from his family or clan ("diurnal regime"). The moment in history at which a religious community led by a charismatic leader (prophet) has degraded into absolute monarchy based on kinship, where legitimacy of ruling usually originates from intentional interpretations of holy texts and different kinds of manipulations to purchase loyalty among aristocrats and marginals can be regarded as the sunrise of "eternal empire" or in other words, the rise of an archetype of empire incorporated into historical memory of next generations on centuries. That is why today historical memory about attempts of gaining legitimacy by community leader can exist as archetypes that define behavioural matrix inside of formal and non-formal social institutions, networks, associations etc.

Ismaili community starts its history from period of struggle for power between two clans Banu Hashim and Banu Umayya after death of Prophet Muhammad. Mentioned community has successfully made attempt to transfer legitimacy of political leadership issue from sacral (religious and spiritual) into marginal space (wars, military conflicts and even murders on political reasons) (Taşpinar Boz \& Biçici, 2019). These two clans had initial disagreements on the question as to who would succeed Prophet as the religious and political authority. As a result, two mazhabs or schools of Islamic jurisprudence were formed, represented by three main branches of Islam: Sunnites (Hanafi, Hanbali, Shafii and Maliki); Shiites (Jafari) and Kharijites (Ibadiyya). Nowadays, most scholars agree that the emergence of mazhabs in Islam was trigged by the events of Saqifah and Karbala and also political turmoil of this period: outcomes of numerous conquests that led to the spread of Islam over a large area, also Islamisation of communities of conquered lands and emergence of distinct political views based on synthesis between Islam and cultures of these peoples, their interpretations of Islam based on values of local cultures and struggle for power that took place in religious context. 
The situation of Shia Islam based on Jafari School (named after Imam Jafar Al-Sadiq) was more sophisticated: there are also subdivisions such as "Twelvers" (followers of Jafar Al-Sadiq's teaching); "Fivers" known as "Zaidiyyah" (named after Zayd ibn Ali, whose imamate they support in place of his brother Muhammad al-Baqir, son of Zayn al-Abidin and the fifth imam) and "Seveners" also known as Ismaili (after name of Jafar al-Sadiq's older son Ismail ibn Jafar al-Mubarak, who was recognised by them after his murder as "appointed seventh imam" instead of his Muhammad al-Baqir, who was recognised by most of Shia community as true Imam).

Ismaili group is considered as one of "ghulat" sects. The term "ghulat" means sectarian groups and their beliefs that are based on "hulul" concept (in other words manifestation, belief that sometimes god can exist in human body of an imam), "tanasukh" (metempsychosis) and "ibana" (rejecting on their behalf law norms such as classical Islamic dogmas). Metempsychosis is defined as a belief in transfer of eternal soul after death of person or animal into new body of the same or different species predictable by imagination (MirKasimov, 2020). Ismaili, like other ghulat sectarians, follow the ideas of divine emanation of part of god's soul into human body of their spiritual leader, thus such notion is green light for numerous interpretations and manipulations by marginal crowd partially involved into sacral sphere. Since the end of $8^{\text {th }}$ century, Ismaili movement was spreading its influence and as result in the $10^{\text {th }}$ century Fatimid Caliphate that controlled territories of contemporary North Africa, Palestine, Syria, Lebanon, Yemen, Sicily, Mecca and Medina (Muslim holy cities) was founded.

Founder of Ismaili state, Hasan Ibn As-Sabbah, was converted into Ismaili sect in his young years and later visited Cairo, where he obtained knowledge and experience as preacher ("dai"); this allowed him to acquire numerous students and followers and proclaim himself as the successor of Prophets of Islam. In 1090 they conquered Alamut fortress near Qazvin in mount region of contemporary Western Iran. Within next few decades, his followers captured fortresses in Rudbar and Qumis valleys, some fort-cities in Kuhistan and castles in the mountainous regions of contemporary territories of Lebanon and Syria. This state existed for 177 years till 1256 when Mongols conquested the citadels of Alamut and Meimundiz. Few years later, in 1273, last Ismaili fortress in the mountainous region of Syria was destroyed by the forces of Egyptian sultan Baybars (Mir-Kasimov, 2020).

According to historians, the state of sectarians under reign of Hasan Ibn As-Sabbah was close to a commune by structure but different in one detail - political power and spiritual authority were concentrated in the hands of one authoritarian leader - Ismaili imam. Ibn As-Sabbah abolished all Seljuk taxes, and instead of this ordered to people from Alamut to build roads, dig channels and build fortresses. For this purpose, the ruler of Alamut invited or kidnapped the best specialists in various fields of science to his fortress, from civil engineers to doctors and alchemists. Ibn As-Sabbah's agents - preachers - also bought rare books and manuscripts containing various knowledge. 
During Medieval ages, followers of Hasan Ibn As-Sabbah risked their lives to build high-conspiratorial networks around Muslim world and beyond, as well as a very effective defensive state doctrine without spending a lot of material resources on regular maintenance of large armies. Ruler of Alamut was the first who has created his own intelligence service aimed at influencing key political figures and their elimination if it was ordered by Ismailia imam-leader.

Ismaili were the first founders of "recruitment" concept based on postulates that followers of imam are purified from all sins and his order is more than law his will was perceived as manifestation of divine reason. Success in recruitment was caused by extraordinary tricks, different illusions and mind coding techniques with use of narcotic drugs (opium poppy - "hashish"). Sitting in his impregnable mountain fortress, Ibn As-Sabbah sent suicide assassins to different lands to spread his influence and exert control.

Terrorist organisation created by Ibn As-Sabbah had a strict hierarchical structure. "Fedayeens" or executioners of death sentences were at the bottom level. They acted in blind obedience and, if they managed to survive for several years, were promoted to the next rank - "rafik." The next in their hierarchical pyramid was the title of "dai"; the will of Ismaili imam was transmitted directly through them. Continuing to move up the hierarchical ladder, it was theoretically possible to rise to status of "dai al-kirbal," who obeyed only the mysterious "Sheikh al-Jabal" hidden from prying eyes, who actually was the "Great Lord of Assassin Order" and the leader of Ismaili state with its capital in Alamut - Sheikh Hassan I Ibn Al-Sabbah (Waterson \& Morgan, 2008). The same hierarchy structures, ideological patterns, recruitment and manipulative techniques can be found in many of contemporary radical groups, military sects and terrorist organisations (Kadivar, 2020).

After the death of Hassan Ibn Al-Sabbah, his spiritual heritage and power were succeeded by his son. Such Ismaili tradition illustrates to us how divine elements (eternal nature of power) and marginal beliefs were mediated and fixed by founders of sacral empire into its concept and archetype. Even after few centuries, grandsons of Ibn Al-Sabbah, according to Ismaili customs, were considered Imams-leaders for millions of sect followers settled around the world.

Shamsuddin Mohammad, the son of the last ruler of Alamut (Rukn Al-Din Khurshah, who was the 27th Ismaili imam), escaped to Tabriz on territory of contemporary Azerbaijan controlled in mentioned above historical period by Iran. Later his grandson, Hasan Ali Shah, who was born in Yazd city (historical territory of contemporary Iran), after death of his father Shah Khalil Allah III, became the 46th Ismaili imam. He was married with Sarv-i Jahan Khanum, daughter of the Shah of Persia, Fath-Ali Shah Qajar. Ruler of Persia granted to Hasan Ali Shah position of governor-general of southern province Kerman. In 1830, 46th Ismaili imam was awarded the honorary title of "Aga Khan" (or "Great Leader") on order of his father-in-law, Shah of Persia; that was a strategic step of Qajari Shah to improve his political influence and to retain the territories of Azerbaijan (where were a lot of Ismaili followers) as a part of his 
empire (Poor, 2014).

After the death of Fath-Ali Shah in 1834, Hasan Ali Shah came into conflict with Mohammed, who was son and successor of Iranian shah. Their conflict was caused by competition for control on Kerman area, where Hasan Ali aspired to act as an independent ruler. However, after two years of confrontation, the Aga Khan was captured along with his many relatives. After a year in prison, he was sent into exile. In 1840 he rebelled against the Shah again; he failed and in 1841 fled to Afghanistan. At this time, the First Anglo-Afghan War was ongoing and, being a guest of the Kandahar governor, Aga Khan became a mediator in the negotiations between British authorities and Afghan leaders that facilitated the evacuation of the British troops (Poor, 2014).

After leaving Afghanistan, Aga Khan settled for two years in Sindh, inhabited by a large and influential Ismaili community. He also was awarded for assistance to British colonial administration in setting control on Baluchistan in 1843: that amounted to the annual pension of 2000 pounds. After that, Aga Khan moved to Bombay and then settled in Calcutta.

In 1866, the High Court of Bombay confirmed the title of Aga Khan and his leadership over all Ismailis: he received the title of "His Highness" (or prince) from British Queen Victoria. Such politically wise step was essentially needed for British colonial administration to improve British influence on Hindustani territories. Since this time, Aga Khan, like his successors, became controlled actor of political games on international arena and institute of Ismaili imamate becomes instrument of cultural diplomacy and key points of soft power strategies of Western Leviathan on Eastern Sphinx territories and beyond (Plekhanov, 2008; Poor, 2014).

Nowadays, the institute of imamate is under the leadership of Karim AlHusayni Shah, the $4^{\text {th }}$ Aga Khan, Persian prince and the $49^{\text {th }}$ Ismaili imam who also has the religious title of "Mawlana Hazar Imam." Karim Al-Husayni has British and Portuguese citizenship and is a well-known business magnate, an owner of racehorses, prominent philanthropist and investor in economic and socio-cultural projects in the third world countries where communities of Ismaili diaspora live (Ismailimail, 2017).

Karim Al-Husayni is an exception in to the traditional perception of monarchs; according to Forbes he is one of 15 richest royals in the world but he does not rule over any geographic territory and all his capital is based not only on assets belonging to his clan: annually each working Ismaili follower should pay traditional tax in favor of their Imam. He has founded and lead one of the largest private development networks in the world named "Aga Khan Development Network" (Poor, 2014). This organisation deals with such issues as improvement of environment, health, education, architecture, culture, microfinance, rural development, disaster reduction, promotion of private-sector entrepreneurship and development of historical cities (Aga Khan Academies, n.d.).

Since 1957 when Karim Al-Husayni became leader of Nizari Ismailis, he as Aga Khan has faced complex political and economic changes that deeply affected his followers. Among them, the most significant were: end of colo- 
nial rule epoch on territory of African continent, banishment of Asians from Uganda, independence from former Soviet Union gained by Central Asian countries such as Tajikistan and continuous turmoil in Afghanistan and Pakistan. Moreover, Karim Al-Husayni became the first Ismaili spiritual leader in history to address the joint session of Canadian parliament (Aga Khan Academies, n.d.).

\section{TRANSLATORS AND MANIPULATORS: SPECULATIONS WITHIN AND BEYOND MEANING AND DISCOURSE}

Manipulative nature of translated or reinterpreted texts also correlates with their discourse. Traditionally, discourse is observed as complex communicative phenomenon that includes text itself and some other aspects of interaction (i.e. the act of sharing information or knowledge, communicative goals and cognitive elements, skills and abilities to conduct constructive intercultural dialogue etc.). All of the things listed above play key roles in successful and adequate interpretation of texts that is very important in work with sacred and religious ones (Naude, 2006).

Intralingual translation takes place if we rephrase an expression, summarise or rewrite it or its fragment in the same language as the source text. Discussing cross-cultural peculiarities of interlingual translation when we deal with two different verbal languages, Israel underlines role of translator's proficiency that is the main precondition of their veracity and transfer in relevant, correct equivalents of symbolic-sacral meanings of source texts.

Two intertwined planes exist: linguistic and conceptual. According to Hephzibah Israel's notion "each of them deals in complex ways to perform the multiple forms of translation that can be identified in religious contexts" (Israel, 2019, pp. 323-324). Sometimes we can find basic elements of religious dogma translated in different ways and represented in simple or more appropriate format for the purpose of recruiting new adepts or better understanding of the text by a wide audience belonging to different cultures.

The term "sacral text" is in general defined as text's fragment, object or sound combination recognised as sacral, holy or used for any such purpose by religious community. That is why scriptural translation of sacred text is only one aspect of translation process that manifests itself in the phenomenon of spreading of religions. Not a phrase that that most of the sacral elements present in the holy texts of each religion are often translated not only for ritual purposes, but also for the needs of poetry, music or recitation created by the members of religious communities. This is aimed to enrich their spiritual practice and introduce them to the cultures from other parts of the world. Sectarians or followers of radical political movements often use the method mentioned above to prove the so-called divine legitimacy of their encroachments on territory, resources or political recognition and marginal support within community and beyond. This point can be illustrated by case with attempts 
to translate meanings of Muslim holy book Quran into Ukrainian language by Valery Basyrov (RAMU, 2012).

Literary experiment of Basyrov entitled Quran: Translations of Meanings into Ukrainian was included on the list of contenders for National Taras Shevchenko Prize of Ukraine in 2011. As an initiative of National Taras Shevchenko Prize of Ukraine Committee, the book was also submitted for expertise to Religious Administration of Muslims of Ukraine. The results of the expertise contained the statement that the book has many fragments that can be used as instruments of manipulative influence on crowd. The experiment was based on literal translation and combination of the fragments of existing earlier Russianlanguage attempts to translate original text of Quran in author's interpretation. Moreover, such literal translation of some of Quran verses was borrowed from Russian sources and reflects the views of Ibn Taymiyah, whose ideas formed ideological basis for many extremist pseudo-Islamic movements and sects. Usually, with such interpretations, extremist movements and sects try to justify and spread their destructive ideology under the mask of Islamic doctrine (Anthony, 1999).

According to Naude (2019), translation of sacred and religious texts requires the translator to have appropriate education, advanced level of knowledge on theology and interpretation of the meaning of religious texts. He proposes six principles of work with sacred texts: translation of religious texts is not essentially different from classical process of translation; translated sacred texts often facilitate cross-cultural communication; interpretation of sacred texts is based on special purposes and does not perform similar communicative functions in modern societies; translator's activity as a process should pay more attention to translation strategies rather than to establishing equivalence between text units; critics use mostly descriptive analysis of interpreted sacred texts rather than normative ones; knowledge in the field of epistemology, hermeneutics and religiosity of translators are the basis of core intellectual and intercultural competences required for the translation of sacred texts (Naude, 2019).

Another interesting case is related to the Indian custom called "suttee" that is often linked in literature to interpretations of myth about Sati (pagan Hindu goddess), who died in fire created by mystical yogic power when her father killed her husband Shiva (Fish, 2006). But only in myth Shiva and Sati remain alive despite death: in practice widows traditionally joined their dead husbands on funeral fure or, in some rare cases, soon after this. Such ritual was propagated among all social groups of Hindu society by Brahmans and members of high castes as ideal of woman's devotion. A similar custom called "jauhar" existed between the $12^{\text {th }}$ and $16^{\text {th }}$ centuries, which involved a woman's self immolation before expected husbands' death in battle; it was widely practiced by Rajputs clans in the period of military conflicts with Mogul Empire to save women from rape, which was considered worse than death from the hands of enemies. Thus, the popularity of "suttee" customs was caused by social stereotypes and economic hardships of widows in Hindu society (Fish, 2006). 
Nowadays one of controversial issues in interreligious dialogue and mediation is the absence of logical connection between sacral texts and their interpretations by representatives of radical circles, who advocate violence as divinelyapproved acts. Thus a complex approach to religious pluralism in global scope is needed, one that is based on wise and well-informed response to the association of terrorism and large-scale violence with religion increasingly shared within communities. In his book, John Renard analyses major scriptures of different religious traditions and explores interpretations of selected fragments from these texts, focusing on those ones that were very often named as sources of inspiration and justification for wide range of violence acts from individual assassination to mass murders. Thus, there exists a need in validation of instruments required for facilitation in reading and understanding of sacral textual sources in light of cross-cultural communication (Renard, 2012).

The most serious among existing threats to successful cross-cultural communication includes language manipulation within and beyond discourse, like it was with the controversial novel The Satanic Verses published in 1988, written by Salman Rushdie, who originates from family of Indian Muslims. Interpreted in author's manner, characters and event canvas in this novel were inspired by life of Prophet Muhammad. Rushdie used magical realism to transfer symbolic and legendary characters to contemporary events as to create his own critical interpretation for the core elements of Islam. That is why novel's name refers to the "satanic verses" that are also known as group of Quran verses that refer to the three pagan idols of Mecca: "Manat," "Al-Lat" and "Uzza" (Rushdie, 2011). Many of Rushdie's books were boycotted in India and beyond as hate words addressed all members of Muslim community as a result of the text. There were several failed attempts to kill Rushdie, who was provided with police protection by British government. There were also some attacks on his colleagues, including the murder of the translator Hitoshi Igarashi.

Also the same outcomes of manipulations with discourse demonstrate to us case of French satirical weekly magazine "Charlie Hebdo" that sarcastically criticises cartoons, jokes, reports and polemics. Office of this magazine suffered three terrorist attacks dated on 2011, 2015 and 2020. During the attack of terrorists in 2011, twelve people were killed including the publishing director Charb and his colleagues-cartoonists (BBC News, 2020).

Frequently, the manipulations within discourse are implemented into verbal and non-verbal aspects of language: when speaker uses the covert means within a language in order to impose on recipient a certain idea of reality, attitude to it, emotional reaction or intention that does not coincide with those that this addressee could form independently. This is the main reason why in digital age informational security becomes a core issue and a trigger of the growing concern that may affect all societal space (Ikenwe et al., 2016). Serhiy Teleshun, an Ukrainian scholar, underlines that absence of information security can provoke situations in which unauthorised users get access to confidential information and as a result, its integrity may be compromised. 
Data security assurance belongs to the sphere of modern strategic interests and national security issues (Teleshun, 2019).

Instrumental domain of societal competition on local and global levels, especially since the beginning of $21^{\text {st }}$ century, has been represented by nonstate actors who create and successfully use different kinds of manipulative techniques to win on soft power field. The most dangerous among the agents of influence mentioned above are: sponsored insiders represented by volunteers of different societal movements and individuals-activists or agents of changes (i.e. "voices from crowd") on instrumental level of soft power concept; destructive out-of-system actors represented by a wide range of radical sectarian networks and extremist political entities (such as the so-called "Islamic State"); pseudo-religious movements (like the Taliban); radical religious and political groups focused mostly on terror and separatism (like "Hizb ut-Tahrir" and "al-Qaida") (Mungur, 2009).

Moreover, information security can be represented by means and instruments of monitoring and control over the information shared by different religious groups, NGOs, opinion-makers and pseudo-experts who pretend to be recognised in public sphere as scholars or spiritual authorities as like as promoter of creationist ideas who is well-known Harun Yahya, who goes by the pen name of Adnan Oktar.

Adnan Oktar is a Turkish televangelist and a leader of destructive sect whose ideology was based on a mix of creationist ideas masked under Islamic rhetoric. Sect members called themselves BAV group and "Adnan Hocacilar" (adherents of Adnan Hodja) in public. Adnan Oktar became well-known in Turkey and beyond especially for provocative TV shows broadcast on his own channel (Kersten \& Olsson, 2016). Sect leader and its members were arrested in 2018 for crimes ranging from harassment and women trafficking to blackmail, money laundering and espionage. Thousands of free copies of his pseudo-scientific book Atlas of Creation with arguments against evolution had been mailed to politicians, journalists, universities and schools around the world with the aim to attract new followers into the sect and improve his own financial status.

Progressive soft power instruments and strategies, as it was identified over the course of our research on the non-state destructive actors activity, are successfully used by them to spread their ideology, lay the foundations of new network branches and to promote their agents on key positions of strategic societal institutes around the world by the means of economic motivation and application of manipulative techniques within cultural-ideological sphere (i.e. corruption and spreading of reinterpreted sacred texts in light of their destructive ideas). Schematically, interrelations between the interpretations of texts grounded in spiritual or cultural values (e.g. sacred texts) and the type of manipulative influence on target audience (community, marginal groups etc.) can be described as follows (see Figure 1). 


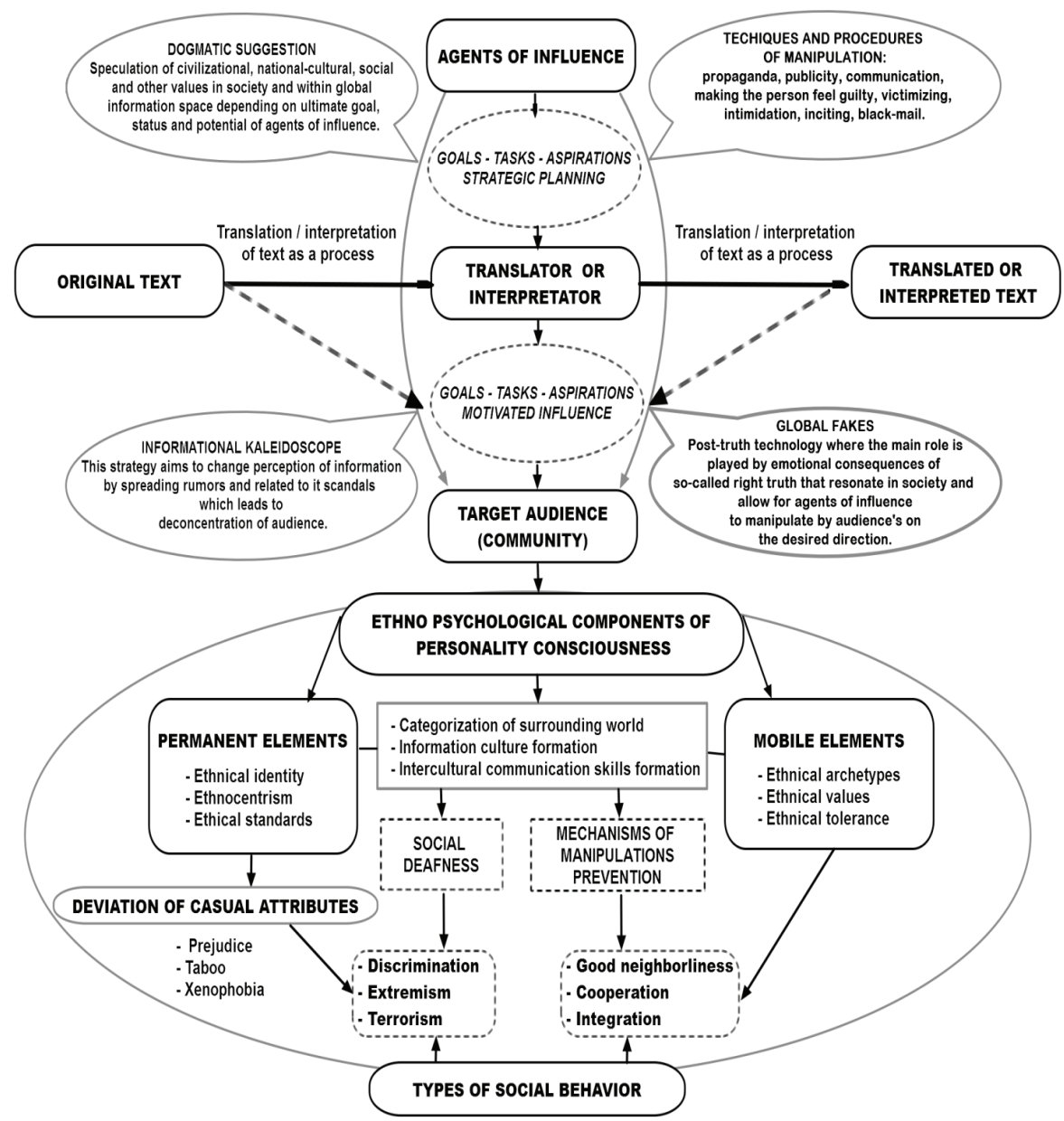

Fig. 1. Manipulative nature of translation: impact on social behaviour.

\section{CONCLUSIONS AND PERSPECTIVES FOR FURTHER RESEARCH}

Digitalisation and development of IT sphere, alongside globalisation, have shifted the role of soft power as unique tool that facilitates the penetration from international public sphere into the national societal space for agents of influence motivated to take total control on national strategic interests and on the development of new agenda for policymaking on local and international level.

However, such manipulative strategies work successfully in practice only under conditions of semi-controlled digital space like we have in Ukraine. Thus, current critical socio-economic situation in Ukraine accelerates risks for our country to share the fate of Libya or Syria, which are currently suffe- 
ring from the consequences of uprisings in MENA countries and their impact on other regions of the world. That is why, to prevent impacts of destructive manipulations and informational attacks (i.e. global fakes) inspired and sponsored from outside by agents of influence, we need to pay additional attention to information security issues on macro and micro levels.

By rethinking "Eranos" School's assumption of cyclical time and eternal return in the light of the Aga Khan's and postmodern case studies, we can summarise that Western leaders, on their behalf, are willing to acknowledge and legitimise the claims to spiritual power and political leadership, even if these claims are based only on mythology and imagination, to improve their own symbolic power and dominance in political and mental-sacral spheres. Eternal empire as an archetype grounds on: different scale and scope of interpretations and speculations on historical memory and spiritual heritage; aspiration of return to mythologised "golden age" perceived by community in real historical period of time (even if duration of that period was very short); claims on political and spiritual leadership, economic dominance and political hegemony (in geographic space and historical time).

Agents of influence usually use different manipulative tactics, including translated interpretations of sacral texts to speculate on peace building, controversial cultural, religious, political and economic issues. Thus, the activity of manipulators and the impact of the tactic-strategic instruments on their target audience can be the object of multidisciplinary research on social and behavioural studies.

\section{ACKNOWLEDGEMENTS}

The article is a revised and extended version of materials published as the report "Manipulative nature of translation: interpreters and interpretations" that was presented on international conference Language and intercultural communication: theory and practice on 25 February 2021 in Poltava, Ukraine (Garnyk \& Vitkovskyi, 2021)1. Term "marginal" in the context of our work is used to describe simplified version of religious doctrine, modified (converted) by spiritual authorities into populist form, which is the most appropriate for perception by crowd of followers, who has mostly marginal origin. We also consider that term "marginal" in some cases can't be synonym of "secular." When "marginal" means "close to crowd," "secular" defines "those that divided from religion and spiritual faith."

1 Garnyk, L., \& Vitkovskyi, Y. (2021). Manipulative nature of translation: interpreters and interpretations. In N. Sizonenko (Ed.), Language and Intercultural Communication: Theory and Practice (pp. 168-180). Kiev: Publisher Lira-K. 


\section{REFERENCES}

[1] Aga Khan Academies. (n.d.). The Aga Khan Academies. Retrieved May, 5 2021, from https:// www.agakhanacademies.org/file/439

[2] Anthony, D. (1999). Pseudoscience and minority religions: An evaluation of the brainwashing theories of Jean-Marie Abgrall. Social Justice Research, 12(4), 421-561.

[3] BBC News. (2020, September 1). Charlie Hebdo: Magazine republishes controversial Mohammed cartoons. Retrieved from https://www.bbc.com/news/world-europe-53985407

[4] Bekkum, K., Jaap Dekker J., van de Kamp, K., \& Peels E. (2017). Playing with Leviathan. Interpretation and reception of monsters from the Biblical world. Themes in Biblical narrative, 21. Leiden: Brill.

[5] Corbin, H. (1983). Cyclical time and Ismaili gnosis. London: Kegan Paul International in association with Islamic Publications Ltd.

[6] de Sacy, A. (1842). Bibliothèque de M. le baron Silvestre de Sacy [Library of Baron Silvestre de Sasi]. Paris: Imprimerie royale.

[7] Dukate, A. (2007). Manipulation as a specific phenomenon in translation and interpreting. (Publication No. 6969). [Doctoral dissertation, University of Latvia]. University of Latvia Research Repository. https://dspace.lu.lv/dspace/bitstream/handle/7/4984/6969-Aiga_ Dukate_2007.pdfsequence $=1$ \&isAllowed $=y$

[8] Dukate, A. (2009). Translation, manipulation and interpreting. Frankfurt am Main: Peter Lang Press.

[9] Durand, G. (1999). The anthropological structures of the imaginary. Brisbane: Boombana Publications.

[10] Dusi, N. (2015). Intersemiotic translation: Theories, problems, analysis. Semiotica, 206, 181-205. https://doi.org/10.1515/sem-2015-0018

[11] Duskers, M. (2020). A global perspective on the mental health response to terrorism. In R. Ursano, E. Vermetten, E. Vermetten, I. Frankova \& L. Carmi (Eds.), Risk management of terrorism induces stress: Guidelines for the golden hours (who, what and when) (pp. 10-21). Amsterdam: IOS Press.

[12] Eliade, M. (2005). The myth of the eternal return: Cosmos and history. Princeton: Princeton University Press.

[13] Fish, J. (2006). Burning women: A global history of widow sacrifice from ancient times to the present. Michigan: Seagull.

[14] Frazer, J. (2012). The golden bough. Cambridge: Cambridge University Press.

[15] Garnyk, L. et. al. (2020). Economic diplomacy in 21st century: Trends, horizons and new actors. In: I. A. Chikarenko (Ed.), Innovacijni instrumenty zabezpechennya investycijnoho ta infrastrukturnoho rozvytku ob'yednanyx terytorialnyx hromad: materialy nauk.-prakt. konf. za mizhnar. uchastyu, 27 lystopada $2020 r$. [Proceedings of the scientific-research conference with international participation "Innovative instruments of assurance the investment and infrastructural development of joint territorial communities," 27 November, 2020] (pp. 330-333). Dnypro: State Regional Institute of Administration of National Academy of Administrative Management.

[16] Hakl, H. (2014). Eranos: An alternative intellectual history of the twentieth century. London and New York: Routledge, Taylor \& Francis Group.

[17] Ikenwe, I., Osahon, M., Igbinovia, M., \& Elogie, A. (2016). Information security in the digital age: The case of developing countries. Chinese Librarianship: An International Electronic Journal, $42,16-24$.

[18] Ismailimail, V. A. P. B. (2017, June 16). The roles of Mawlana Shah Karim al-Husayni Hazar Imam - Aga Khan IV. Ismailimail.blog. Retrived from https://ismailimail.blog/2017/06/14/ the-roles-of-mawlana-shah-karim-al-husayni-hazar-imam-aga-khan-iv/

[19] Israel, H. (2019). Translation and religion: Crafting regimes of identity. Religion, 49(3), $323-$ 342. https:// doi.org/10.1080/0048721x.2019.1635332

[20] Jakobson, R. (1959). On linguistic aspects of translation. In: A. Fang et al. (Eds.), On translation (pp. 232-239). Cambridge, Mass: Harvard University Press.

[21] Kadivar, J. (2020). Exploring Takfir, its origins and contemporary use: The case of Takfiri approach in Daesh's media. Contemporary Review of the Middle East, 7(3), 259-285. https:/ / doi. org $/ 10.1177 / 2347798920921706$ 
[22] Kersten, C., \& Olsson, S. (2016). Alternative Islamic discourses and religious authority. London and New York: Routledge.

[23] Kuey, L. (2020). Role of media / social media in aftermath of violent acts. In E. Vermetten, I. Frankova \& L. Carmi. (Eds.), Terror attacks. Risk management of terrorism induces stress: Guidelines for the golden hours (who, what and when) (pp. 152-165). Amsterdam: IOS Press.

[24] Laugharne, R., \& Laugharne, J. (2002). Psychiatry, postmodernism and postnormal science. Journal of the Royal Society of Medicine, 95(4), 207-210. https:/ / doi.org/10.1258/jrsm.95.4.207

[25] Maffesoli, M. (1996). The contamination of the world: Figures of community style. (S. Emanuel, Trans.). Minneapolis-London: University of Minnesota Press.

[26] McLeod, S. (2018, May 21). Carl Jung. Simply Psychology. Retrieved from https://www.simplypsychology.org/carl-jung.html

[27] Mir-Kasimov, O. (Ed.). (2020). Intellectual interactions in the Islamic world. London: I. B. Tauris in association with Institute of Ismaili Studies.

[28] Mungur, K. (2009). Islamist distortions: Hizb ut-Tahrir a breeding ground for Al-Qaida recruitment. Journal of Strategic Security, 2(4). https:/ / doi.org/10.5038/1944-0472.2.4.6

[29] Naude, J. (2006). The Qu'rān in English. An analysis in Descriptive Translation Studies. Journal for Semiotics, 15(2), 431-464.

[30] Naude, J. (2010). Religious translation. In: Y. Gambier (Ed.), Handbook of Translation Studies, Volume 1 (pp. 285-293). Amsterdam: John Benjamins Publishing Company.

[31] Nida, E. (1969). Science of translation. Language, 45(3), 483, 98-108. https://doi. org/10.2307/411434

[32] Otto, R. (1958). The idea of Holy. New York: Oxford University Press.

[33] Plekhanov, S. (2008). Raskrytaja ladon'. Aga-Han i ego mjuridy. [Open hand. Agha-Khan and his Murids]. Moscow: Books World.

[34] Poor, D. M. (2014). Authority without territory: The Aga Khan development network and the Ismaili Imamate (literatures and cultures of the Islamic world). New York: Palgrave Macmillan.

[35] RAMU. (2012, May 15). Ne vse to zoloto, chto blestit: o popytke perevoda V. Basyrovym Svjashhennogo Kur ana na ukrainskij jazyk. [Not all that gold if shining ones: about climes of V. Basyrov to translate Holy Quran into Ukrainian language]. Retrieved from https:/ / biblioteka.islam.ua/ literatura/buklety/ne-vse-to-zoloto-chto-blestit/

[36] Renard, J. (2012). Fighting words: Religion, violence and the interpretation of sacred texts. Berkley, Los Angeles, London: University of California Press.

[37] Rushdie, S. (2011). The Satanic Verses. London: Vintage Books.

[38] Taşpinar Boz, Z., \& Biçici, M. (2019). Nusayriliğe Ve Nusayri Ideolojisine Genel Bir Bakış (Suriye Örneği) [An overview of Nusayri and Nusayri ideology (case study of Syria)]. Social Sciences Studies Journal, 5(33), 2119-2131. https:/ / doi.org/10.26449/sssj.1415

[39] Teleshun, S. (2019). Human Resource Management in an unstable world. World experience and Ukrainian realities. Bulletin of the NAPA, Series Public Administration, 1(92), 60-66.

[40] Waterson, J. (2008). The Ismaili assasins: A history of medieval murder. London: Frontline Books. 